\title{
Peningkatan Kemampuan Komunikasi Matematis Siswa Menggunakan Pembelajaran Kooperatif Tipe Two Stay Two Stray (TSTS) Berbantuan Teknik Scaffolding
}

\author{
Agus Subiyakto, Intan Sari Rufiana, Dwi Avita Nurhidayah
}

(C) 2020 JEMS (Jurnal Edukasi Matematika dan Sains)

This is an open access article under the CC-BY-SA license (https://creativecommons.org/licenses/bysa/4.0/) ISSN 2337-9049 (print), ISSN 2502-4671 (online)

\begin{abstract}
Abstrak:
Penelitian ini bertujuan untuk mendeskripsikan implementasi pembelajaran kooperatif tipe Two Stay Two Stray (TSTS) berbantuan teknik Scaffolding. Penelitian ini juga untuk mengetahui kemampuan komunikasi matematis siswa dan hasil belajar siswa setelah implementasi pembelajaran kooperatif tipe Two Stay Two Stray (TSTS) berbantuan teknik Scaffolding. Penelitian ini dilakukan di kelas VIIIC SMPN 1 Siman pada tahun pelajaran 2019/2020. Desain Penelitian Tindakan Kelas (PTK) dilakukan dalam 2 siklus, yang mana instrumen pengumpulan datanya dalam bentuk soal tes dan lembar observasi. Didasarkan pada hasil temuan, terdapat peningkatan hasil belajar siswa dari siklus 1 dan siklus 2 setelah diterapkan pembelajaran Two Stay Two Stray (TSTS) dengan teknik scaffolding. Begitu juga dengan kemampuan komunikasi siswa juga meningkat. Beberapa hal yang harus diperhatikan dalam implementasi pembelajaran ini adalah pertama, guru harus memperhatikan alokasi waktu yang disediakan setiap langkah pembelajaran sesuai dengan Rencana Pelaksanaan Pembelajaran. Kedua, guru harus mengotimalkan perannya sebagai fasilitator dalam pembelajaran kooperatif tipe Two Stay Two Stray (TSTS) melalui berbagai macam teknik scaffolding. Beberapa teknik yang diberikan disini bisa diadaptasikan dengan model-model pembelajaran dan materi yang lain. Guru perlu selektif untuk memilih teknik yang tepat untuk terlaksananya pembelajaran yang optimal.
\end{abstract}

Kata Kunci: Komunikasi Matematis, Two Stay Two Stray, Scaffolding

\begin{abstract}
:
The aim of this study is to describe the implementation of Two Stay Two Stray (TSTS) cooperative learning assisted by Scaffolding techniques. This study is also to determine students' mathematical communication skills and student learning outcomes after the implementation of Two Stay Two Stray (TSTS) cooperative learning assisted by Scaffolding techniques. This research was conducted in class VIIIC of SMPN 1 Siman at 2019/2020 academic year. The Classroom Action Research (CAR) design was carried out in 2 cycles, in which the data collection instruments were in the form of test questions and observation sheets. Based on the findings, there is an improvement in student learning outcomes from cycle 1 and cycle 2 after applying Two Stay Two Stray learning (TSTS) assisted by scaffolding techniques. Furthermore, the communication skills of students are also increased. Some points that must be considered in implementating this learning procedures are firstly, teachers must pay attention to the allocation of time provided for each step of learning in accordance with the Learning Implementation Plan. Secondly, the teacher must optimize his role as a facilitator in cooperative learning type Two Stay Two Stray (TSTS) through various scaffolding techniques. Some of the techniques given here can be adapted to other learning models and materials. The teacher needs to be more selective in choosing the right technique for optimalizing learning.
\end{abstract}

Keywords: Mathematical Communication Skill, Two Stay Two Stray, Scaffolding.

Agus Subiyakto, SMPN 1 Siman Ponorogo

agussubyakto69@gmail.com

Intan Sari Rufiana, Universitas Muhamadiyah Ponorogo

intan.sari.rufiana@gmail.com

Dwi Avita Nurhidayah, Universitas Muhamadiyah Ponorogo

avitadwi17@gmail.com 


\section{Pendahuluan}

Komunikasi matematis pada pembelajaran matematika sangatlah penting. Sebagaimana dituliskan dalam NCTM (2000) dan Permendikbud nomor 58 Tahun 2014 bahwa salah satu focus utama yang menjadi tujuan dalam pembelajaran matematika di sekolah adalah kemampuan komunikasi matematis. Dalam Peraturan Menteri Pendidikan Nasional No 22 Tahun 2006 tentang Standar Isi untuk satuan Pendidikan Dasar dan Menengah mata pelajaran matematika disebutkan bahwa salah satu tujuan pembelajaran matematika adalah agar siswa memiliki kemampuan mengkomunikasikan gagasan dengan simbol, tabel, diagram, atau media lain untuk memperjelas keadaan atau masalah. Demikian juga dijelaskan oleh Sokoine (2015) bahwa keterampilan dalam berkomunikasi sangatlah penting dalam rangka untuk perolehan keterampilan komunikasi yang akan diperlukan dalam kehidupan akademik mereka nantinya.

Siswa yang memiliki kemampuan dalam komunikasi matematis akan mampu dan terampil dalam mengaplikasikan ide-ide matematika yang diwujudkan dalam bentuk lisan maupun tulisan. Siswa yang memiliki kemampuan komunikasi akan dapat menyampaikan ide dan pikiran mereka baik kepada guru maupun ke siswa lain. Siswa yang mempunyai kemampuan komunikasi matematis akan mempermudah dalam mengkonstruksi konsep matematika, mengembangkan kemampuan pemecahan masalah dan meningkatkan kemampuan penalaran. Tidak hanya itu, siswa yang mempunyai kemampuan komunikasi matematis juga akan tumbuh rasa percaya diri dalam diri mereka, hal ini tentunya akan meningkatkan keterampilan sosial.

Menurut Baroody (1993), ada dua alasan penting mengapa komunikasi menjadi salah satu fokus dalam pembelajaran matematika. Yang pertama adalah pada dasarnya matematika adalah sebuah bahasa bagi matematika itu sendiri. Matematika bukan hanya merupakan alat bantu untuk berfikir yang membantu kita untuk menemukan pola, memecahkan masalah dan menarik kesimpulan, tetapi juga sebuah alat untuk mengkomunikasikan pikiran kita tentang berbagai ide dengan jelas, tepat dan ringkas. Bahkan, matematika dianggap sebagai bahasa universal dengan simbol-simbol dan struktur yang unik. Semua orang di dunia dapat menggunakannya untuk mengkomunikasikan informasi matematika meskipun bahasa asli mereka berbeda. Yang kedua bahwa belajar matematika merupakan aktifitas sosial yang melibatkan paling sedikit dua pihak, yaitu guru dan siswa.

Komunikasi matematis dapat didefinisikan dari dua istilah yaitu komunikasi dan matematis. Komunikasi adalah suatu proses penyampaian informasi, dapat diartikan pula sebagai suatu proses penyampaian gagasan dari seseorang terhadap orang lain, komunikasi juga diartikan sebagai proses penciptaan arti terhadap gagasan atau pun ide yang disampaikan (Majid, 2013). Dalam NCTM (2000) dijelaskan bahwa standar kemampuan komunikasi matematis yang harus dikuasai siswa adalah a. Mengorganisasi dan mengkonsolidasi pemikiran matematika dan mengkomunikasikan kepada siswa lain b. Mengekspresikan ide-ide matematika secara koheren dan jelas kepada siswa lain, guru, dan lainnya. c. Meningkatkan atau memperluas pengetahuan matematika siswa dengan cara memikirkan pemikiran dan strategi siswa lain. $d$. Menggunakan bahasa matematika secara tepat dalam berbagai ekspresi matematika. Indikator ini yang digunakan peneliti untuk menyusun instrumen penelitian yaitu lembar observasi.

Berbeda dengan harapan di atas, pada kenyataannya jika dilihat dilihat di lapangan, kemampuan komunikasi siswa tergolong rendah. Penelitian yang dilakukan oleh Hernawati, dkk (2013) mendukung pernyataan ini. Berdasarkan observasi di kelas pun dapat diamati bahwa mayoritas siswa kurang aktif. Observasi pada pembelajaran matematika yang dilakukan peneliti di kelas VIIIC SMPN 1 Siman, meskipun guru sudah memahamkan siswa melalui contoh dan 
bukan contoh, meminta siswa untuk menyusun pertanyaan terkait dengan topik, meminta siswa untuk menjawab pertanyaan. Namun pada saat pembelajaran matematika adalah yang menjawab pertanyaan hanyalah siswa-siswa tertentu, siswa cenderung pasif, tidak memperhatikan saat pembelajaran, tidak mau ketika diminta untuk presentasi di depan kelas ataupun hanya sekedar mengerjakan soal di depan kelas, siswa juga cenderung tidak percaya diri.

Dari hasil refleksi ini, kelemahan dari hasil pembelajaran matematika adalah pada kemampuan komunikasi siswa. Hal inilah yang menyebabkan hasil belajar matematika siswa kelas VIIIC masih tergolong rendah. Sebagaimana hasil penelitian Daimaturrohmatin dan Rufiana (2019) dijelaskan bahwa penelitian selanjutnya diarahkan untuk mengimplementasikan model pembelajaran tertentu yang dapat digunakan untuk meningkatkan kemampuan komunikasi matematis siswa. Oleh karena itu, kemampuan komunikasi matematis haruslah menjadi perhatian utama dalam pembelajaran matematika.

Sesuai dengan Teori Perkembangan Piaget, siswa SMP masuk pada tahap operasional formal. Karateristik siswa pada tahap ini adalah dimilikinya kemampuan untuk berfikir abstrak, menalar secara logis dan menarik kesimpulan dari informasi yang disediakan. Dalam pembelajaran, mereka membutuhkan kegiatan yang dapat memfasilitasi kemampuan untuk belajar secara logis dan menarik kesimpulan dari informasi yang disediakan oleh guru ataupun siswa yang lain. Salah satu model pembelajaran yang dapat digunakan untuk pembelajaran seperti ini adalah model pembelajaran kooperatif. Berbagai bentuk model pembelajaran kooperatif dapat digunakan dalam pembelajaran, tetapi yang memungkinkan untuk dapat meningkatkan kemampuan komunikasi matematis siswa adalah pembelajaran kooperatif tipe Two Stay Two Stray (TSTS).

Pemanfaatan model pembelajaran kooperatif tipe Two Stay Two Stray TSTS akan mensetting siswa untuk aktif dalam berdiskusi, bertanya dan menjawab, presentasi dan juga menyimak penjelasan teman. Pembagian dua siswa yang tinggal dan dua siswa yang berkeliling adalah pembagian tugas yang jelas untuk setiap kelompok ahli. Sebagaimana dijelaskan oleh Jollife (2007) bahwa two stay two stray adalah penggabungan dua kelompok dengan kelompok lain untuk mendiskusikan dan menyelesaikan tugas untuk kemudian kembali ke kelompok asal untuk mendapatkan feedback. Seide dengan hal ini dijelaskan oleh Budiyanto (2016) bahwa model pembelajaran kooperatif tipe Two Stay Two Stray (TSTS) merupakan suatu model pembelajaran dimana siswa disetting dalam kelompok belajar untuk belajar bersama, kemudian dua siswa dari kelompok itu akan bertukar informasi dengan dua anggota kelompok lain yang tinggal di kelompok.

Oleh karena itu, kemampuan komunikasi matematis haruslah menjadi perhatian utama dalam pembelajaran matematika. Sesuai dengan Teori Perkembangan Piaget, siswa SMP masuk pada tahap operasional formal. Karakteristik siswa pada tahap ini adalah dimilikinya kemampuan untuk berpikir abstrak, menalar secara logis dan menarik kesimpulan dari informasi yang tersedia. Dalam pembelajaran, mereka membutuhkan kegiatan yang dapat memfasilitasi kemampuan untuk menalar secara logis dan menarik kesimpulan dari informasi yang disediakan oleh guru ataupun siswa yang lain. Sudah ada beberapa penelitian terkait dengan kemampuan komunikasi matematis siswa ini. Salah satunya adalah penelitian tentang analisis kemampuan komunikasi siswa ditinjau dari gaya belajar Kolb yang dilakukan oleh Daimaturrohmatin dan Rufiana. Rekomendasi penelitian Daimaturrohmatin dan Rufiana (2019) untuk penelitian selanjutnya adalah bahwa perlu dilakukan penelitian lanjutan mengenai model pembelajaran agar kemampuan komunikasi matematis siswa meningkat. 
Salah satu model pembelajaran yang dapat digunakan untuk pembelajaran seperti ini adalah model pembelajaran kooperatif. Berbagai bentuk model pembelajaran kooperatif dapat digunakan dalam pembelajaran, tetapi yang memungkinkan untuk dapat meningkatkan kemampuan komunikasi matematis siswa adalah pembelajaran kooperatif tipe Two Stay Two Stray (TSTS). Dijelaskan oleh Ratnasari, dkk (2015) bahwa model pembelajaran kooperatif tipe TSTS merupakan salah satu tipe dalam pembelajaran kooperatif yang memfasilitasi siswa untuk mempunyai pengalaman berbagi pengetahuan baik dengan siswa dalam satu kelompok maupun siswa kelompok lainnya. Model pembelajaran kooperatif tipe Two Stay Two Stray (TSTS) mempunyai tujuan agar siswa dapat bekerja sama dalam menemukan konsep.

Pemanfaatan model pembelajaran kooperatif tipe Two Stay Two Stray (TSTS) akan mensetting siswa untuk aktif dalam berdiskusi, bertanya dan menjawab, presentasi dan juga menyimak penjelasan teman. Pembagian dua siswa yang tinggal dan dua siswa yang berkeliling adalah pembagian tugas yang jelas untuk setiap kelompok ahli. Sebagaimana dijelaskan oleh Jollife (2007) bahwa two stay two stray adalah penggabungan dua kelompok dengan kelompok lain untuk mendiskusikan dan menyelesaikan tugas untuk kemudian kembali ke kelompok asal untuk mendapatkan feedback. Seide dengan hal ini dijelaskan oleh Budiyanto (2016) bahwa model pembelajaran kooperatif tipe Two Stay Two Stray (TSTS) merupakan suatu model pembelajaran dimana siswa disetting dalam kelompok belajar untuk belajar bersama, kemudian dua siswa dari kelompok itu akan bertukar informasi dengan dua anggota kelompok lain yang tinggal di kelompok.

Adapun langkah-langkah model pembelajaran kooperatif tipe Two Stay Two Stray (TSTS) menurut Huda (2014) dan Sari, dkk. (2019) adalah sebagai berikut: 1)sebelum kegiatan TSTS berlangsung, guru memberikan petunjuk di awal pembelajaran untuk mengenalkan bahan yang sesuai dengan Rencana Pelaksanaan Pembelajaran yang dibuat. 2) Kemudian baru dilanjutkan dengan pembentukan kelompok. siswa dikelompokkan dengan masing-masing jumlah anggota kelompok 4 siswa, 3) guru memberikan tugas pada setiap kelompok untuk didiskusikan, 4) setelah diskusi, 2 siswa dari masing-masing kelompok diminta untuk meninggalkan kelompoknya dan bertamu ke kelompok lain, 5) dua siswa yang masih ada pada kelompok asal bertugas menjelaskan tugas dan hasil kerja kelompok lain kepada tamu mereka, 6) Tamu memohon diri dan kembali kepada kelompok mereka semula dan melaporkan apa yang telah mereka dapatkan dari kelompok lain, 7) setiap kelompok membandingkan dan membahas hasil pekerjaan mereka semua. 8) Guru berkeliling dari satu kelompok ke kelompok lain untuk memastikan setiap siswa menguasai bahan pelajaran mereka melalui scaffolding, 9) setelah tugas kelompok dikumpulkan, siwa diminta untuk mengerjakan kuiz secara individu, 10) kemudian guru mengoreksi kuiz dan menggabungkan skor quiz pada masing-masing kelompok. Nilai total kuiz yang kurang dari 300 setiap kelompok akan mengulang kuiz lagi.

Sebagaimana model pembelajaran yang lain, model pembelajaran Two Stay Two Stray juga memiliki kelemahan. Kelemahan dalam model pembejalaran kooperatif tipe Two Stay Two Stray (TSTS) yang dijelaskan oleh Hamdi, dkk (2014) bahwa karena penyampaian materi terlalu singkat, maka saat pembelajaran kooperatif tipe Two Stay Two Stray (TSTS) siswa masih banyak yang bertanya terkait materi. Kadiriandi dan Ruyadi (2017) adalah suasana kelas cenderung gaduh dan guru cenderung kesulitan dalam melakukan pengelolaan kelas untuk itu membutuhkan persiapan materi dan tenaga. Hal ini diperkuat oleh hasil penelitian Nurdayana, dkk (2016) yang menunjukkan bahwa aktivitas guru dalam pembelajaran kooperatif tipe Two Stay Two Stray (TSTS) persentasenya adalah 60\% dengan kategori kurang baik. Dalam pengelolaan kelas guru kurang bisa mengelola suasana kelas, guru juga kurang tegas untuk 
menegur siswa yang bercerita dan mengingatkan waktu ketika berdiskusi dengan kelompok gabungan. Guru juga lupa memberikan penghargaan terhadap kelompok yang tampil.

Merujuk pada beberapa kelemahan di atas, model pembelajaran kooperatif tipe Two Stay Two Stray (TSTS) ini akan efektif jika dipadukan dengan metode scaffolding oleh guru. Ketika guru berkeliling ke setiap kelompok untuk memastikan setiap siswa menguasai bahan pelajaran mereka, guru menggunakan teknik scaffolding. Scaffolding adalah metafora yang mengacu pada cara dimana orang dewasa atau teman-teman yang lebih canggih menyediakan dukungan untuk anak-anak yang sedang belajar pada mereka (Bruner, 1957; Wood, Bruner, \& Ross, 1976; Vygotsky, 1978). Dalam pembelajaran scaffolding, guru mempunyai peran yang vital sebagaimana dijelaskan oleh Sutiarso, 2009 bahwa guru memberi bantuan pada siswa dalam menuntaskan tugas dan konsep yang pada awalnya tidak mampu siswa peroleh secara mandiri. Dari sini dapat dijelaskan bahwa ketika siswa belajar dan belum mampu untuk menguasai konsep, guru bertugas membantu siswa dalam mengkonstuksi konsep tersebut. Ada beberapa teknik scaffolding yang dapat digunakan oleh guru ketika pembelajaran berlangsung.

Teknik scaffolding yang dimaksud dalam penelitian ini adalah teknik yang telah digunakan oleh Zurek, dkk. (2014). Deskripsi dari teknik ini adalah sebagai berikut: 1) Elicting, guru memberikan bantuan berupa pernyataan atau pertanyaan yang membangkitkan respons dari siswa; 2) Inferential Questioning, guru membantu mahasiswa untuk menggunakan bukti untuk menggambarkan kesimpulan, 3) Predicting, membantu siswa untuk membuat prediksi, 4) Drawing Attention to Relevant Features of a Problem or of The Environment, membantu mahasiswa menggunakan "'sense" untuk mempersempit bidang pengamatan menuju fokus penyelidikan atau wacana saat ini; ini bisa dalam bentuk pernyataan atau pertanyaan, 5) Give Hints, guru memberikan petunjuk untuk membantu penyelidikan anak yang berkelanjutan, 6) Provide Materials, guru menyediakan alat untuk mendukung kegiatan atau penyelidikan yang sedang berlangsung, 7) Validation Feedback, pernyataan yang mengomunikasikan "ya, itu benar", 8) Correction Feedback, ketika seorang anak membuat pernyataan yang secara faktual tidak akurat atau menggunakan istilah dengan cara yang tidak akurat, guru menawarkan informasi untuk mengklarifikasi fakta yang sebenarnya tidak akurat, 9) Denomination, guru memberikan istilah yang tepat untuk konsep setelah seorang anak menggunakan istilah yang tidak jelas atau salah. atau belum menggunakan istilah (misalnya, menunjuk), 10) Expansion, guru menambahkan informasi ke pernyataan yang dibuat anak itu, 11) Generalization, guru menyebutkan konsep yang lebih tinggi (kasus umum) yang terkait dengan contoh spesifik yang diidentifikasi oleh seorang anak, 12) Exemplary, guru memberikan contoh spesifik dari konsep umum yang dinamai atau disebut oleh seorang anak, 13) Link to Previous Knowledge and/or Experience, guru merujuk pada apa yang dia ketahui adalah pengalaman atau pengetahuan anak sebelumnya untuk menjawab pertanyaan baru, 14) Co-participating, guru menghitung bersama dengan anak, memulai urutan atau mengisi angka, 15) Contextualization, menarik pengetahuan baru lebih dekat dengan menciptakan tingkat representasi menengah baru untuk menghubungkan konsep yang diperkenalkan dengan orang lain bahwa anak-anak membangun pengalaman langsung, 16) DeContextualization, menjauhkan konsep dari konteks saat ini.

Dari beberapa kajian di atas, tujuan dari kajian yang dipaparkan disini adalah untuk mendeskripsikan implementasi pembelajaran menggunakan kooperatif TSTS berbantuan scaffolding. Penelitian ini juga dilakukan untuk mengetahui kemampuan komunikasi siswa dan hasil belajar siswa setelah implementasi pembelajaran kooperatif TSTS berbantuan scaffolding. 


\section{Metode}

Penelitian yang digunakan adalah jenis Penelitian Tindakan Kelas (PTK). Penelitian Tindakan Kelas adalah penelitian dengan ciri utamanya terdiri dari tindakan-tindakan yang berulang dengan metode utamanya adalah refleksi diri (Nuraeni, 2017). Tujuan utama Penelitian Tindakan Kelas adalah untuk memperbaiki kualitas pembelajaran. Tujuan penelitian ini adalah untuk memperbaiki kualitas metode pembelajaran yang diterapkan yang hasilnya nanti dapat digunakan untuk meningkatkan kemampuan komunikasi dan hasil belajar siswa.

Penelitian ini diimplementasikan di kelas VIIIC SMPN 1 Siman Ponorogo. Pembelajaran dilaksanakan setiap hari Senin dan Sabtu. Subjek penelitian terdiri dari 24 siswa yang terdiri dari 14 siswa laki-laki dan 10 siswa perempuan. Siswa mempunyai karakteristik yang berbeda jika dilihat dari kemampuannya. Sedangkan usia siswa kelas VIIIC SMPN 1 Siman antara 13-15 tahun.

Dalam penelitian ini digunakan dua teknik pengumpulan data yaitu observasi dan tes. Teknik pengumpulan data observasi digunakan untuk mengumpulkan data aktifitas pembelajaran guru dan komunikasi siswa. Sedangkan teknik tes digunakan untuk mengumpulkan data terkait dengan hasil belajar siswa. Analisis data hasil observasi pembelajaran dan catatan lapangan dilakukan dari saat observasi sampai dengan akhir siklus dengan analisis diskriptif kualitatif. Data hasil observasi pembelajaran dan komunikasi siswa dianalisis dengan menghitung prosentase menggunakan rumus sebagai berikut:

dengan

$$
P_{i j}=\frac{T}{M} \times 100 \%
$$

$P_{i j} \quad$ : prosentase keterlaksanaan pembelajaran guru setiap pertemuan/ prosentase kemampuan komunikasi siswa

i : pertemuan ke 1, 2, 3 dst

j : siklus ke 1, 2, 3, dst

$\mathrm{T} \quad$ : total skor keseluruhan

M : jumlah skor maksimal

Kemudian untuk memperoleh rata-rata hasil observasi pembelajaran dan komunikasi siswa setiap siklus menggunakan rumus:

dengan:

$$
\bar{P}=\frac{\sum P_{i j}}{N}
$$

$\bar{P} \quad$ : prosentase rata-rata

$\mathrm{N}$ : banyaknya pertemuan

Dari nilai ini kemudian dikategorikan menggunakan kategori sebagai berikut:

Tabel 1. Kategori Hasil Observasi Pembelajaran Guru dan Komunikasi Siswa

\begin{tabular}{cc}
\hline Prosentase & Kategori \\
\hline $66.67 \% \leq \bar{P} \leq 100 \%$ & Baik \\
\hline $33.33 \% \leq \bar{P}<66.67 \%$ & Cukup \\
\hline $0 \% \leq \bar{P}<33.3 \%$ & Kurang \\
\hline
\end{tabular}


Sedangkan data hasil belajar siswa dianalisis dengan menghitung nilai tes siswa setiap akhir siklus. Nilai tes siswa setiap akhir siklus dihitung dengan menggunakan rumus:

dengan

$$
N=\frac{A}{T} \times 100 \%
$$

$\mathrm{N} \quad$ : prosentase hasil belajar siswa

A : siswa yang memenuhi KKM

$\mathrm{T} \quad$ : jumlah siswa keseluruhan

Adapun indikator keberhasilan yang digunakan dalam penelitian ini adalah sebagai berikut:

1. Pembelajaran dengan menggunakan kooperatif tipe Two Stay Two Stray (TSTS) dengan teknik scaffolding dikatakan selesai apabila masuk dalam kategori baik

2. Kemampuan komunikasi siswa dikatakan memenuhi apabila masuk dalam kategori baik

3. Hasil belajar siswa dikatakan berhasil jika nilai prosentase lebih dari $80 \%$

\section{Hasil dan Pembahasan}

\section{A. Siklus 1}

Pembelajaran matematika yang dilaksanakan dengan model pembelajaran kooperatif tipe Two Stay Two Stray (TSTS) siklus 1 dilaksanakan dua kali dengan alokasi 2 jam pembelajaran yaitu 2 × 40 menit. Pertemuan pertama dilaksanakan pada hari Sabtu tanggal 31 Agustus 2019. Pertemuan kedua dilaksanakan pada hari Senin tanggal 2 September 2019. Prosentase keterlaksanaan pembelajaran oleh guru setiap pertemuan disajikan dalam tabel berikut ini:

Tabel 2. Prosentase Keterlaksanaan Pembelajaran Oleh Guru pada Siklus 1

\begin{tabular}{cccc}
\hline No & Pertemuan ke- & Prosentase & Kategori \\
\hline 1 & Pertama & $76 \%$ & Baik \\
\hline 2 & Kedua & $88 \%$ & Baik \\
\hline
\end{tabular}

Dari tabel di atas, dapat dilihat bahwa prosentase keterlaksanaan pembelajaran yang dilakukan oleh guru dalam kategori baik dan terdapat peningkatan prosentase keterlaksanaan pembelajaran dari pertemuan pertama ke pertemuan kedua. Namun beberapa langkah pembelajaran belum dilaksanakan dengan baik oleh guru karena terkendala beberapa hal. Diantaranya adalah guru belum dapat mengkondisikan siswa pada saat proses pembelajaran. Hal ini dikarenakan siswa belum terbiasa mengikuti pembelajaran dengan model pembelajaran kooperatif tipe Two Stay Two Stray (TSTS) dengan teknik scaffolding.

Dari pihak guru sendiri masih kurang mampu memberikan scaffolding saat berkeliling dari satu kelompok ke kelompok lain, seperti guru belum mampu memberikan bantuan berupa pertanyaan/ pernyataan yang dapat membangkitkan respon siswa. Guru juga belum membantu siswa untuk membuat prediksi, membantu siswa menggunakan "sense" untuk mempersempit bidang pengamatan bidang pengamatan menuju fokus penyelidikan.

Guru sudah melakukan scaffolding dalam bentuk memberikan istilah yang tepat dari suatu konsep setelah seorang anak menggunakan istilah yang tidak jelas seperti ketika siswa menyebutkan rumus fungsi dengan menyebutkan $f$ dalam kurung $x$, guru meluruskan $f(x)$ cukup dibaca fungsi f dalam $x$. Guru juga sudah merujuk pada apa yang diketahui siswa dari 
pengalaman dan pengetahuan yang didapat sebelumnya. Prosentase kemampuan komunikasi siswa setiap pertemuan disajikan dalam tabel berikut ini:

Tabel 3. Prosentase Kemampuan Komunikasi Siswa pada Siklus 1

\begin{tabular}{cccc}
\hline No & Pertemuan ke- & Prosentase & Kategori \\
\hline 1 & Pertama & $32 \%$ & Kurang \\
\hline 2 & Kedua & $60 \%$ & Cukup \\
\hline
\end{tabular}

Dari tabel di atas, dapat dilihat bahwa terdapat peningkatan prosentase kemampuan komunikasi siswa, hanya saja kemampuan siswa ini masuk dalam kategori kurang dan cukup. Kendalanya adalah belum mampunya siswa untuk memberikan penjelasan kepada anggota kelompok lain yang bertamu. Meskipun sebagian siswa sudah memahami pokok bahasan yang dipelajari, namun ketika diminta untuk menjelaskan ke kelompok lain siswa merasa kesulitan. Yang dilakukan siswa hanya membaca hasil pekerjaannya tanpa memberikan keterangan tambahan.

\section{B. Siklus 2}

Pembelajaran matematika yang dilaksanakan dengan model pembelajaran kooperatif tipe Two Stay Two Stray (TSTS) dengan teknik scaffolding siklus 2 dilaksanakan dua kali dengan alokasi 2 jam pembelajaran yaitu $2 \times 45$ menit. Pertemuan pertama dilaksanakan pada hari Sabtu tanggal 7 September 2019. Pertemuan kedua dilaksanakan pada hari Senin tanggal 9 September 2019. Prosentase keterlaksanaan pembelajaran oleh guru setiap pertemuan disajikan dalam tabel berikut ini:

Tabel 4. Prosentase Keterlaksanaan Pembelajaran Oleh Guru pada Siklus 2

\begin{tabular}{cccc}
\hline No & Pertemuan ke- & Prosentase & Kategori \\
\hline 1 & Pertama & $90 \%$ & Baik \\
\hline 2 & Kedua & $92 \%$ & Baik \\
\hline
\end{tabular}

Dari tabel di atas, dapat dilihat bahwa prosentase keterlaksanaan pembelajaran yang dilakukan oleh guru dalam kategori baik dan terdapat peningkatan prosentase keterlaksanaan pembelajaran dari pertemuan pertama ke pertemuan kedua. Beberapa langkah pembelajaran yang belum dilaksanakan dengan baik oleh guru pada siklus 1 sudah dilakukan perbaikan yang didasarkan dari hasil refleksi. Scaffolding juga sudah lancar diimplementasikan oleh guru. Hal ini juga berdampak pada kemampuan komunikasi siswa, yang hasilnya dituliskan pada Tabel 5 berikut ini:

Tabel 5. Prosentase Kemampuan Komunikasi Siswa pada Siklus 2

\begin{tabular}{cccc}
\hline No & Pertemuan ke- & Prosentase & Kategori \\
\hline 1 & Pertama & $60 \%$ & Cukup \\
\hline 2 & Kedua & $75 \%$ & Baik \\
\hline
\end{tabular}

Dari tabel di atas, dapat dilihat bahwa terdapat peningkatan prosentase kemampuan komunikasi siswa dan juga kategorinya. Kemampuan komunikasi siswa mulai baik seperti sudah mulai mampu untuk memberikan penjelasan pada siswa yang berkunjung. Siswa yang 
berkunjung juga sudah bisa menjelaskan konsep yang diterimanya pada anggota kelompoknya. Adapun hasil belajar siswa setiap siklus ditunjukkan pada Grafik berikut:

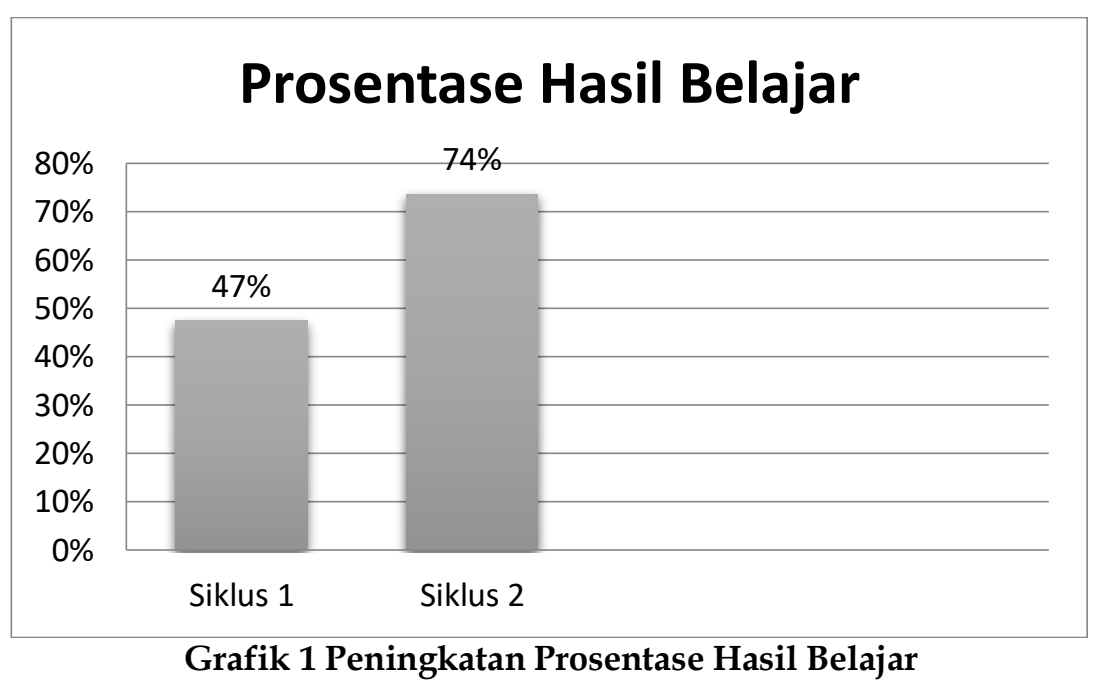

Dari grafik di atas terlihat bahwa ada peningkatan prosentase hasil belajar siswa dari siklus 1 ke siklus 2. Hasil belajar siswa pada siklus 1 adalah $47 \%$, sedangkan pada siklus 2 sudah dapat mencapai $74 \%$. Sehingga peningkatan dari siklus 1 ke siklus 2 adalah sebesar $27 \%$. Didasarkan pada hasil temuan, terdapat peningkatan hasil belajar siswa dari siklus 1 dan siklus 2 setelah diterapkan pembelajaran kooperatif tipe Two Stay Two Stray (TSTS) dengan teknik scaffolding. Begitu juga dengan kemampuan komunikasi siswa. Ini berarti bahwa model pembelajaran kooperatif tipe Two Stay Two Stray (TSTS) dengan teknik scaffolding cocok untuk diterapkan. Temuan ini mendukung beberapa penelitian sebelumnya yaitu Hamdi (2014) yang menjelaskan bahwa terdapat peningkatan keterlaksanaan RPP, keterampilan sosial siswa, dan hasil belajar siswa ketika pembelajaran kooperatif tipe Two Stay Two Stray (TSTS) diterapkan. Penelitian lain adalah penelitian yang dilakukan oleh Hidayat, dkk (2018) yang menemukan bahwa nilai rata kelas meningkat dengan adanya pembelajaran kooperatif tipe Two Stay Two Stray (TSTS).

Hal ini juga diimbangi dengan peningkatan komunikasi belajar siswa. Adanya peningkatan komunikasi belajar siswa dikarenakan dalam pembelajaran TSTS siswa mempunyai kesempatan untuk berbagi pengetahuan dengan siswa lain baik dari anggota kelompoknya sendiri maupun anggota kelompok lain. Ada beberapa kendala dalam implementasi pembelajaran kooperatif tipe Two Stay Two Stray (TSTS) teknik scaffolding diantaranya sebagai berikut: Pertama guru belum dapat mengkondisikan siswa pada saat proses pembelajaran. Hal ini dikarenakan siswa belum terbiasa mengikuti pembelajaran dengan model pembelajran kooperatif tipe Two Stay Two Stray (TSTS) teknik scaffolding. Kedua guru sendiri masih kurang mampu memberikan scaffolding saat berkeliling dari satu kelompok ke kelompok lain, seperti guru belum mampu memberikan bantuan berupa pertanyaan/ pernyataan yang dapat membangkitkan respon siswa. Guru juga belum membantu siswa untuk membuat prediksi, membantu siswa menggunakan "sense" untuk mempersempit bidang pengamatan bidang pengamatan menuju fokus penyelidikan. Ketiga, siswa belum mampu untuk memberikan penjelasan kepada anggota kelompok lain yang bertamu. Meskipun sebagian siswa sudah memahami pokok bahasan yang dipelajari, namun ketika diminta untuk menjelaskan ke 
kelompok lain siswa merasa kesulitan. Yang dilakukan siswa hanya membaca hasil pekerjaannya tanpa memberikan keterangan tambahan.

Beberapa cara yang dilakukan untuk memperbaiki beberapa kendala di atas adalah sebagai berikut: Pertama, guru harus memperhatikan alokasi waktu yang disediakan setiap langkah pembelajaran sesuai dengan Rencana Pelaksanaan Pembelajaran. Kedua, guru harus mengotimalkan perannya sebagai fasilitator dalam pembelajaran kooperatif tipe Two Stay Two Stray (TSTS) teknik scaffolding yang direkomendasikan oleh Zurek, dkk. (2014). Beberapa teknik yang diberikan oleh Zurek ini bisa diadaptasikan dengan model-model pembelajaran dan materi yang diajarkan. Beberapa teknik Zurek ini memang tidak sesuai jika diimplementasikan pada sebarang materi matematika. Peran guru untuk memilih teknik sangat diharapkan demi terlaksananya pembelajaran yang optimal.

\section{Simpulan}

Berdasarkan analisis data maka dapat disimpulkan bahwa model pembelajaran kooperatif tipe Two Stay Two Stray (TSTS) teknik scaffolding dapat meningkatkan komunikasi matematis dan hasil belajar siswa kelas VIIIC SMP N 1 Siman dengan prosentase kemampuan komunikasi matematis siklus 1 yaitu $60 \%$ dan siklus 2 menjadi $75 \%$. Sedangkan hasil belajar siklus 1 yaitu $47 \%$ meningkat menjadi $74 \%$ pada siklus 2 .

\section{Daftar Rujukan}

Baroody, A.J. 1993. Problem Solving, Reasoning and Communicating. New York: Macmillan Publishing.

Budiyanto, A.K. 2016. Sintaks 45 Metode Pembelajaran dalam Student Centered Learning (SCL). Malang: UMM Press.

Bruner, J.S. 1957. Going beyond the information given. New York: Norton.

Daimaturrohmatin dan Rufiana, I.S. 2019. Analisis Kemampuan Komunikasi Matematis Siswa Ditinjau dari Gaya Belajar Kolb. Jurnal Ilmiah Mahasiswa, 3(1): 17-31.

Hernawati, K. , Mahmudi, A., dan Lestari, H.P. 2012. The Role of Problem Solving Method on The Improvement of Mathematical Learning. International Scientiffic Publication and Consulting Service (ISPACS), 1-9.

Hamdi, R., Jamal, M.A., Annur, S. 2014. Meningkatkan Hasil Belajar Fisika dengan Menerapkan Model Pembelajaran Kooperatif Tipe Two Stay Two Stray. Berkala Ilmiah Pendidikan Fisika, 2(3), 265273.

Hidayat, M.T., Daroni, Setijowati, U. 2018. Peningkatan Pembelajaran Materi Pesawat Sederhana di Sekolah Dasar melalui Model Two Stay Two Stray. Pancasakti Science Education Journal, 3(2), 65 72 .

Huda, M. 2014. Model-model Pengajaran dan Pembelajaran. Yogyakarta: Pustaka Pelajar.

Jollife, W. 2007. Cooperative Learning in the Classroom. London: Paul Chapman. 
Kadiriandi, R \& Ruyadi, Y. 2017. Pengaruh Penerapan Model Pembelajaran Model Two Stay Two Stray (TSTS) terhadap Peningkatan Keaktifan dan Hasil Belajar Sosiologi di SMA Pasundan 3 Bandung. Sosietas, 7(2): 429-433.

Majid, Abdul. 2013. Strategi Pembelajaran. Bandung: Remaja Rosdakarya.

NCTM. 2000. Principles and Standards for School Mathematics. Reston: NCTM.

Nuraeni, Zuli. 2017. Penerapan Metode Peer Teaching Pada Mata Kuliah Kapita Selekta Matematika Pendidikan Menengah Untuk Meningkatkan Pemahaman Mahasiswa Terhadap Kisi-Kisi Soal Un Matematika Smp. Jurnal Silogisme : Kajian Ilmu Matematika dan Pembelajarannya, [S.1.], v. 2, n. 2, p. 84-91.

Nurdayana, Sumarno, Feny Trisnawati. 2016. Penerapan Model Pembelajaran Two Stay Two Stray (TSTS) untuk Meningkatkan Hasil Belajar Siswa pada Mata Pelajaran Ekonomi di Kelas X ${ }^{1}$ SMAN 3 Tanah Putih Kecamatan Tanah Putih Kabupaten Rokan Hilir. Jurnal Online Mahasiswa, 3(2): 1-9.

Peraturan Menteri Pendidikan Nasional No 22 Tahun 2006.

Permendikbud Republik Indonesia Nomor 58 tahun 2014 tentang Kurikulum 2013 Sekolah Menengah Pertama/Madrasah Tsanawiyah. 2014. Jakarta: Kemendikbud.

Ratnasari, Mardiyana, Usodo, B. 2015. Eksperimen Model Pembelajaran Kooperatif Tipe Two Stay Two Stray dengan Pendekatan Saintifik (TSTS-PS) dan Tipe Teams Assissted Individualization dengan Pendekatan Saintifik (TAI-PS) pada Materi Himpunan Ditinjau dari Kecemasan Belajar Matematika Siswa Kelas VII SMP Negeri Se-Kabupaten Karanganyar. JMEE, v(1):1-11.

Sokoine, S.C.K. 2015. The Perceived Importance of Communication Skills Couerses among University Students: The Case of Two Universities in Tanzania. International Journal of Education and Research, 3(2), 497-508.

Sutiarso, Sugeng. 2009. Scaffolding dalam Pembelajaran Matematika. Prosiding Seminar Nasional Penelitian, Pendidikan dan Penerapan MIPA Fakultas MIPA, Universitas Negeri Yogyakarta, 16 Mei 2009.

Vygotsky, L.S. 1978. Mind an Society: The Development of Higher Mental Processess. Cambridge, MA: Harvard University Press.

Wood, D., Bruner, J.S., \& Ross, G. 1976. The Role of Tutoring in Problem Solving. Journal of Child Psychology and Psychiatry, 17(2), 89-100.

Zurek, A., Torquati, J., Acar, I. 2014. Scaffolding as a Tool for Environment Education in Early Chilhood. International Journal of Early Chilhood Environmental Education, 2(1), 27-57. 